\title{
How did you become a driver: differences in history of traffic offenses and accident involvement?
}

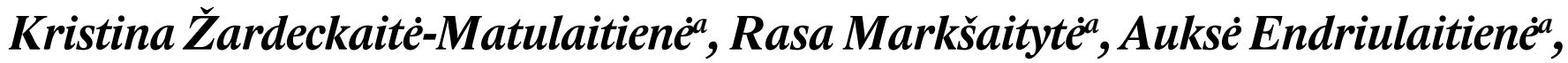 \\ Laura Šeibokaitéa , Justina Slavinskienéa
}

${ }^{a}$ Vytautas Magnus University, Jonavos St.66-328, Kaunas LT-44191, Lithuania

ABSTRACT: Novice drivers are considered as the riskiest group of drivers due to caused accidents and injuries related to inexperience and propensity to take risks on the road. Thus, prospective analysis of importance of driving learning history for the novice drivers' future involvement in traffic violations or road accidents is extremely encouraged. This study is aimed to evaluate the importance of learning to drive experience and driving test (theory and on-road) performance for the prediction of objective traffic rules violations and later accident involvement in Lithuanian novice drivers. 598 learner drivers who obtained their driving licence for the first time participated in the longitudinal study. Information concerning their learning to drive experience before taking driving test, theory test and on-road driving test performance was obtained in the first stage of the study. Later information on the number of recorded traffic offenses committed by participants and number of accidents during the first year of their independent driving was obtained from the police records. The results showed that worse driving theory test performance, but not on-road driving test performance was related to the fact of being fined for traffic rules violations. While age and experience of learning to drive were not important predictors of being a traffic offender. Gender and length of independent driving were also important predictors for later traffic violations.

This research was funded by a grant from the Research Council of Lithuania (grant No. GER005/2015).

KEYWORDS: Learner drivers; traffic rules offences; accident involvement; driving theory test performance; on-road driving test performance

\section{INTRODUCTION}

Novice drivers are considered as the most vulnerable group of drivers all over the world (Boccara, Delhomme, Vida-Gomel, \& Rogalski, 2011; de Winter, 2013). In Europe drivers aged from 16 to 24 years have 1.7 times more chances to die in an accident compared to other age groups and such high crash rates among novice drivers remain quite stable (Traffic Safety Basic Facts, 2016). Lithuania together with Poland, Romania and Bulgaria are leading countries of traffic injuries caused by novice drivers in Europe. For example, in 201512.3 percent of all traffic accidents were caused by novice drivers with less than two years of experience of independent driving (Recorded accident statistics in Lithuania, 2016). Moreover, statistics show that novice drivers tend to violate traffic rules, which can increase the probability of accident on the road. The most common violations according to Lithuanian Police Service (2017) are speeding (78.8 percent of novice drivers), drunk driving (20 percent of them), and other different violations (2.2 percent).

Different psychological characteristics have been studied as correlates of risky driving in novice drivers. Personality traits, especially such as sensation seeking, impulsivity, and aggressiveness (Berdoulat, Vavassori, \& Sastre, 2013; Ge, Qu, Jiang, Du, Sun, \& Zhang, 2014; Harris et al., 2014; Poó \& Ledesma, 2013; Yang, Du, Qu, Gong, \& Sun, 2013), positive attitudes towards risky driving (Cacciabue, 2007; Isler, Starkey, \& Sheppard, 2008; Ram \& Chand, 2015), low resistance to peer influence (Møller \& Haustein, 2014; Shope, 2006; Shope, Raghunathan, \& Patil, 2003), or poor ability to deal with own emotions (Berdoulat et al., 2013; Trógolo, Melchior, \& Medrano, 2014) were found to be important contributors to the increased risk of traffic rules violations or accidents in this group of drivers. However, 
most authors confirmed the first 6 or 12 months of independent driving to be a crucial period for road accident involvement and traffic rules violations because of insufficient driving experience and overestimation of own driving skills (Baughan, Sexton, Simpson, Chinn, \& Quimby, 2006; Borowsky \& Shinar, \& Oron-Gilad, 2010; Boufous, Ivers, Senserrick, \& Stevenson, 2011; de Winter, 2013; Redshaw, 2005; Scott-Parker et al., 2014).

It is expected that driving training develops appropriate driving skills and safe driving attitudes and provides necessary driving experience for safe independent driving. But generally, in most countries driving training is focused on manoeuvring and car control skills rather than on driving safety. Even though Baughan and colleagues (2006) noted that candidates choose to take driving test not prepared enough: when their driving competence give only a moderate probability of passing the test. Therefore, the fact of passing the driving test does not guarantee being a good or even a moderate driver. In fact, those novice drivers, who barely pass a driving test, later independently drive less mileage, avoid driving in challenging conditions and thus may hinder the further development of their driving skills (Baughan et al., 2006; Harré, Foster, \& O'Neill, 2005; Sexton \& Grayson, 2010; Wells, Tong, Grayson, \& Jones, 2008). On the other hand, further skill training due to more frequent driving after being licenced might lead to increased driving self-confidence. Thereby novice drivers overestimate their abilities to manage challenging road situations and develop limited hazard perception skills that might contribute significantly to increased accident involvement and intentional traffic rules violations too (Baughan et al., 2006; Starker \& Isler, 2016; Vassallo et al., 2014).

In line with these findings history of learning to drive and driving test performance might be important predictors of novice drivers' future involvement in traffic violations. Nevertheless, research focusing on driving related issues in the training period and later accident involvement is scare (Boufous et al., 2011; Vassallo, et al., 2007). Actually, we were able to find only four studies that investigated this relationship between driving test performance and later accident involvement in novice drivers. Three studies examined the impact of the driving test outcomes on the likelihood of traffic accidents in three different cohorts of novice drivers in UK (Baughan et al., 2006; Baughan \& Sexton, 2002; Maycock \& Forsyth, 1997; Sexton \& Grayson, 2010) and one study reported data from the sample of Australian novice drivers (Boufous et al., 2011). So, this study is aimed to investigate the predictive value of learning to drive experience and driving test (theory and on-road) performance for the prediction of objective traffic rules violations and later accident involvement in Lithuanian novice drivers. Driver education and training program in Lithuania is not structured and mostly focused on knowledge of traffic rules and car control skills (Šeibokaitè, Endriulaitienè, Markšaitytè, \& Žardeckaitè-Matulaitienè, 2011) while Australia, UK and some other European countries use the Goals for Driver Education model which focuses more on safety issues in driving training and testing (Mynntinen et al., 2009; Simons-Morton \& Ehsani, 2016). Thus, we hope that this study would add beneficial information to the existing knowledge in the field.

Baughan and colleagues (2006) found that longer supervised driving training might decrease accident risk of novice drivers during the first 6 months of their independent driving. Nyberg \& Gregersen (2007) stated that structured driving training also helps to perform better during on-road driving tests. However, Maycock \& Forsyth (1997) did not find any relation between length of driving training and later accident involvement. They even argued that accident vulnerability increased with more supervised driving practice because less competent learner drivers took more driving lessons from different supervisors just to pass the driving test. Thus, we hypothesize that those novice drivers who had more diverse driving training experience (not only under the supervision of driving instructor) would be more prone to violate traffic rules and would be more likely to become involved in an accident while independent driving.

Previous research confirmed the positive relationship between failures during on-road driving test and higher accident involvement while later independent driving in novice drivers (Baughan et al., 2006; Baughan \& Sexton, 2002; Boufous et al., 2011; Maycock \& Forsyth, 1997; Sexton \& Grayson, 2010). However, Sexton \& Grayson (2010) stated that firsttime passers of on-road driving test reported riskier driving style even though had lower accident involvement liability. De Winter (2013) also confirmed that traffic rules violations during simulation-based driver training were related to later self-reported violations while independent driving. Based on this we assume that novice drivers who passed the on-road driving test at the first attempt would be more prone to violate traffic rules but less involved in accidents. 
While those, who pass theory test from the first attempt, would be less prone to violate traffic rules as they had better initial knowledge and understanding about proper driving requirements. Unfortunately, none results on accident liability or traffic rules violations due to performance in driving theory test were reported in previous literature.

\section{METHODOLOGY}

\subsection{Participants}

Learner drivers were invited to participate in this study on voluntary basis. The invitation was sent using web-page of the state enterprise "Regitra", which is responsible for drivers' licensing in Lithuania. Using this online platform, participants were given informed consent and were asked to fill in the self-report questionnaire, concerning various psychological characteristics and learning to drive features before they made a reservation time for their on-road driving test procedure. Participants' personal information (name and surname) was asked in order to relate their data to the driving test (theory and on-road) performance and police records on traffic rules violations during the first year of independent driving. Ethical approval for the study was obtained from the Ethics Committee of Psychology at the Department of Psychology at Vytautas Magnus University in Lithuania.

598 learner drivers (262 males, 336 females) participated in this study. Their age ranged from 17 to 58 years $(\mathrm{M}=23.63, \mathrm{SD}=8.31)$. Female participants were slightly older than males (mean age of females $\mathrm{M}=24.72, \mathrm{SD}=9.07$, mean age of males $\mathrm{M}=22.22$, $\mathrm{SD}=6.98$, Student $\mathrm{t}=-3.81, \mathrm{df}=595.9, \mathrm{p}<.001)$. Twothirds of all participants (71\%) were younger than 25 years. 22.9 percent of the respondents had university education and $77.1 \%$ of them had lower than university education. The mean of the driving days after being licensed was 360.43 days ( $S D=92.83$, range was from 1 to 512 days). No gender differences in the duration of independent driving were found (Mann Whitney $\mathrm{U}=42005.50, \mathrm{p}=.34$ ).

\subsection{Measures}

For the purposes of this paper, information about learning to drive experience (one question "With whom you learned to drive?": (1) only with driving instructor, (2) with driving instructor and under super- vision of other experienced drivers; (3) with instructor, other drivers and independently) and theory as though as on-road driving test performance variables (number of attempts) were collected. Additionally, demographical data concerning gender, age, education level and duration of independent driving was also obtained. Information about drivers committed traffic rules violations and accident involvement during the first year of independent driving was obtained from the police records.

\section{RESULTS}

First, information concerning learner drivers training experience, driving test performance, objective traffic rules violations, and accident involvement was analysed. The descriptive statistics are presented in Table 1 . It could be seen that more male than female learner drivers were learning to drive not only under the supervision of other drivers but also independently (while not being licenced). Higher number of male novice drivers was fined for any traffic rules violations and more males were fined more than one time for these violations compared to female novice drivers. Also, those novice drivers, who were fined for any traffic rules violations, reported longer independent driving after being licensed (Mann Whitney $\mathrm{U}=$ 16701.00, $\mathrm{p}=.001)$.

More thorough analysis of traffic rules violation types showed that more than a half of traffic rules offenders were those who exceeded speed limits (57.3 percent; $n=43$ ); additionally, 10.7 percent of them $(n=8)$ drove without seat belt or disregarded traffic signs. However, due to low number of novice drivers who were fined for the traffic rules violations during the period of their independent driving (12.5 percent), only two types of traffic offenders' groups were analysed later: being fined for the traffic rules violations (yes/no) and number of fines for the traffic rules violations (none/one/more than one) without splitting them according to driver gender or type of committed violation.

When analysing the driving test performance and traffic accident involvement no gender differences were observed. Approximately two thirds of learner drivers passed theory test and almost one third passed the on-road driving test on the first attempt. And only 3.5 percent of all study participants were involved in an objectively recorded traffic accident during first year of independent driving. 
Table 1: Sample characteristics.

\begin{tabular}{|c|c|c|c|c|}
\hline Characteristic & $\begin{array}{l}\text { Total sample } \\
(\mathrm{N}=598)\end{array}$ & $\begin{array}{l}\text { Male } \\
(\mathrm{N}=262)\end{array}$ & $\begin{array}{l}\text { Female } \\
(\mathrm{N}=336)\end{array}$ & $\chi^{2}$ \\
\hline Learning to drive & & & & $14.99 * *$ \\
\hline With driving instructor & $254(42.5 \%)$ & $116(44.3 \%)$ & $138(41.1 \%)$ & \\
\hline With driving instructor and under supervision of other drivers & $315(52.7 \%)$ & $124(47.3 \%)$ & $191(56.8 \%)$ & \\
\hline With driving instructor, other drivers, and independently & $29(4.8 \%)$ & $22(8.4 \%)$ & $7(2.1 \%)$ & \\
\hline Driving theory test performance & & & & $.87 \mathrm{~ns}$ \\
\hline Number of attempts & $1-13$ & $1-13$ & $1-11$ & \\
\hline Passed at the first attempt & $401(67.1 \%)$ & $181(69.1 \%)$ & $220(65.5 \%)$ & \\
\hline Passed at the second or later attempt & $197(32.9 \%)$ & $81(30.9 \%)$ & $116(34.5 \%)$ & \\
\hline On-road driving test performance & & & & $1.08 \mathrm{~ns}$ \\
\hline Number of attempts & $1-17$ & $1-13$ & $1-17$ & \\
\hline Passed at the first attempt & $183(30.6 \%)$ & $86(32.8 \%)$ & $97(28.9 \%)$ & \\
\hline Passed at the second or later attempt & $415(69.4 \%)$ & $176(67.2 \%)$ & $239(71.1 \%)$ & \\
\hline Being fined for the traffic rules violations & & & & $25.12 * *$ \\
\hline Yes & $75(12.5 \%)$ & $53(20.2 \%)$ & $22(6.5 \%)$ & \\
\hline No & $523(87.5 \%)$ & $209(79.8 \%)$ & $314(93.5 \%)$ & \\
\hline Number of being fined for the traffic rules violations & & & & $25.13 * *$ \\
\hline None & $523(87.5 \%)$ & $209(79.8 \%)$ & $314(93.5 \%)$ & \\
\hline One time & $62(10.3 \%)$ & $44(16.8 \%)$ & $18(5.4 \%)$ & \\
\hline More than one time & $13(2.2 \%)$ & $9(3.4 \%)$ & $4(1.2 \%)$ & \\
\hline $\begin{array}{l}\text { Accident involvement during the first year of independent } \\
\text { driving }\end{array}$ & $21(3.5 \%)$ & $8(3.1 \%)$ & $13(3.9 \%)$ & $.29 \mathrm{~ns}$ \\
\hline Yes & $577(96.5 \%)$ & $254(96.9 \%)$ & $323(96.1 \%)$ & \\
\hline No & & & & \\
\hline
\end{tabular}

${ }^{*} \mathrm{p}<.01 ; * * \mathrm{p}<.001$

Table 2: Analysis of traffic rules violations according to the learning to drive experience and driving test performance.

\begin{tabular}{|c|c|c|c|c|c|c|c|}
\hline \multirow[t]{2}{*}{ Characteristic } & \multicolumn{3}{|l|}{ Being fined } & \multicolumn{4}{|c|}{ Number of fines } \\
\hline & Yes $(\mathrm{N}=75)$ & No $(\mathrm{N}=523)$ & $\chi^{2}$ & $\begin{array}{l}\text { No fines } \\
(\mathrm{N}=523)\end{array}$ & One $(\mathrm{N}=62)$ & $\begin{array}{l}2 \text { and } \\
\text { more } \\
(\mathrm{N}=13)\end{array}$ & $\chi^{2}$ \\
\hline \multicolumn{8}{|l|}{ Learning to drive } \\
\hline With driving instructor & $32(12.6 \%)$ & $222(87.4 \%)$ & $.05 \mathrm{~ns}$ & $222(87.4 \%)$ & $29(11.4 \%)$ & $3(1.2 \%)$ & $5.02 \mathrm{~ns}$ \\
\hline $\begin{array}{l}\text { With driving instructor and under } \\
\text { supervision of other drivers }\end{array}$ & $39(12.4 \%)$ & $276(87.6 \%)$ & & $276(87.6 \%)$ & $31(9.8 \%)$ & $8(2.5 \%)$ & \\
\hline $\begin{array}{l}\text { With driving instructor, other } \\
\text { drivers, and independently }\end{array}$ & $4(13.8 \%)$ & $25(86.2 \%)$ & & $25(86.2 \%)$ & $2(6.9 \%)$ & $2(6.9 \%)$ & \\
\hline \multicolumn{8}{|l|}{ Driving theory test performance } \\
\hline Passed at the first attempt & $44(11.0 \%)$ & $357(89.0 \%)$ & $2.73 \mathrm{~ns}$ & $357(89.0 \%)$ & $35(8.7 \%)$ & $9(2.2 \%)$ & $3.53 \mathrm{~ns}$ \\
\hline $\begin{array}{l}\text { Passed at the second or later } \\
\text { attempt }\end{array}$ & $31(15.7 \%)$ & $166(84.3 \%)$ & & $166(84.3 \%)$ & 27 (13.7 \%) & $4(2.0 \%)$ & \\
\hline \multicolumn{8}{|l|}{ On-road driving test performance } \\
\hline Passed at the first attempt & $30(16.4 \%)$ & $153(83.6 \%)$ & $3.57 \mathrm{~ns}$ & $153(83.6 \%)$ & $24(13.1 \%)$ & $6(3.3 \%)$ & $3.85 \mathrm{~ns}$ \\
\hline $\begin{array}{l}\text { Passed at the second or later } \\
\text { attempt }\end{array}$ & 45 (10.8 \%) & $370(89.2 \%)$ & & $370(89.2 \%)$ & 38 (9.2 \%) & 7 (1.7 \%) & \\
\hline
\end{tabular}

${ }^{*} \mathrm{p}<.01 ;{ }^{*} \mathrm{p}<.001$ 
Later the importance of learning to drive experience and driving test performance for traffic violations was evaluated. Cross tabulation of being fined for the traffic rules violations or accident involvement in the groups of different learning to drive experience as though as driving test performance was made using Chi-square criteria. Results are presented in Table 2 and Table 3 .

It could be seen from Table 2 that none of the independent variables (theory and on-road driving test performance or type of learning to drive) was related to the traffic rules violations when all these variables were analysed separately. The same results were obtained when analysing accident involvement: neither learning to drive experience nor theory or on-road driving test performance differed according to the novice drivers' accident involvement during the first year of independent driving (Table 3).

In order to evaluate the cumulative effect of all important demographical factors, driving experience and driving test performance variables for prediction of traffic rules violations, binary logistic and ordinal regression analysis were conducted. Firstly, prediction of being fined for the traffic rules violations was done using gender, age, duration of independent driving after being licenced, learning to drive experience as well as theory test and on-road driving test performance as significant variables which might be

Table 3: Analysis of accident involvement according to learning to drive experience and driving test performance.

\begin{tabular}{llll}
\hline Characteristic & \multicolumn{2}{l}{ Accident involvement } & \\
\cline { 2 - 4 } & Yes (N=21) & No (N=577) & $\chi^{2}$ \\
\hline Learning to drive & & & $1.51 \mathrm{~ns}$ \\
With driving instructor & $8(3.1 \%)$ & $246(96.9 \%)$ & \\
With driving instructor and under supervision of other drivers & $13(4.1 \%)$ & $302(95.9 \%)$ & \\
With driving instructor, other drivers, and independently & $0(.0 \%)$ & $29(100.0 \%)$ & \\
Driving theory test performance & & & \\
Passed at the first attempt & $13(3.2 \%)$ & $388(96.8 \%)$ & $.61 \mathrm{~ns}$ \\
Passed at the second or later attempt & $8(4.1 \%)$ & $189(95.9 \%)$ & \\
On-road driving test performance & & & $.22 \mathrm{~ns}$ \\
Passed at the first attempt & $9(4.9 \%)$ & $174(95.1 \%)$ & \\
Passed at the second or later attempt & $12(2.9 \%)$ & $403(97.1 \%)$ & \\
\hline
\end{tabular}

${ }^{*} \mathrm{p}<.01 ;{ }^{* *} \mathrm{p}<.001$

Table 4: Predictions of being fined for traffic rules violation by learner drivers' gender, age, type of learning to drive, duration of driving experience, and driving test performance $(\mathrm{N}=598)$.

\begin{tabular}{lllll}
\hline Variables & B & SE B & Wald & $\beta$ \\
\hline Age & -.04 & .02 & 3.39 & $.96 \mathrm{~ns}$ \\
Gender (male) $^{\mathrm{a}}$ & 1.22 & .28 & 19.44 & $3.140^{* *}$ \\
Duration of driving experience $^{*}$ & .00 & .00 & 5.86 & $1.00^{*}$ \\
Driving theory test performance (at the first attempt) & -.52 & .27 & 3.85 & $.59^{*}$ \\
On-road driving test performance (at the first attempt) & .23 & .27 & .73 & $1.26 \mathrm{~ns}$ \\
Learning to drive b & & & \\
Only with driving instructor & .20 & .59 & .12 & $1.22 \mathrm{~ns}$ \\
With driving instructor and under supervision of other drivers & .09 & .59 & .02 & $1.09 \mathrm{~ns}$ \\
Nagelkerke $\mathrm{R}^{2}$ & .13 & & & \\
Chi-square & $42.20^{* *}$ & & & \\
\hline
\end{tabular}

${ }^{*} \mathrm{p}<.01 ;{ }^{* *} \mathrm{p}<.001 ;{ }^{\mathrm{a}}$ reference category - females; ${ }^{\mathrm{b}}$ reference category - with driving instructor, other drivers, and independently. 
related to the traffic rules violations in the regression model. Results, presented in Table 4, show that the regression model is statistically significant and probability to become a traffic offender during the first year of independent driving could be predicted by some variables measured beforehand. Probability of being fined for the traffic violations is larger for male novice drivers, those who have longer experience of independent driving, and those who were not firsttime passers of the theory test. On-road driving test performance was not important predictor of fines for traffic rules violations.

Later ordinal regression analysis was made with dependent variable "number of traffic offences" (reference category - none), and all aforementioned independent variables. The results are presented in Table 5. The analysis showed that only gender (being male) and duration of driving (more days of independent driving) after being licenced were important predictors differentiating number of traffic rules violations. Theory test and on-road driving test performance or type of learning to drive were not important for the prediction of number of traffic violations.

Analysis of accident involvement prediction $(1=$ being involved in accident; $0=$ not being involved in accident) by participants' gender, age, type of learning to drive, duration of independent driving and driving test performance was not possible as binary logistic regression model was not statistically signifi- cant (Chi-square $=7.65 ; \mathrm{df}=7 ; \mathrm{p}<.36$; Nagelkerke $\mathrm{R}$ square $=.05)$. So, it could be said that accident involvement could not be predicted by factors, related to driving learning experience and other demographical variables in this study sample.

\section{DISCUSSION}

Previous research has highlighted the importance of different psychological characteristics that contribute to high vulnerability of novice drivers; however, the importance of learning to drive history and driving test performance remains under-investigated. Thus, this paper is devoted to assess the predictive value of learning to drive experience and driving test (theory and on-road) performance for objective traffic rules violations and accident involvement in Lithuanian novice drivers.

Data of this study revealed that 67 percent of study participants passed driving theory test and only 30.6 percent of them passed on-road driving test at the first attempt. The pass rate of theory test was very similar to those reported in the literature: first-time passers usually make up from 49 to 98 percent of all candidates in different countries (Nyberg \& Gregersen, 2007; Sexton \& Grayson, 2010; Singapore police force, 2018; Statista, 2018; Wells et al., 2008). But the pass rate of on-road driving test was

Table 5. Prediction of number of fines for traffic rules violations by learner drivers' gender, age, type of learning to drive, duration of driving experience, and driving test performance $(\mathrm{N}=598)$.

\begin{tabular}{llll}
\hline Variables & B & SE B & Wald \\
\hline Number of being fined for the traffic rules violations ${ }^{a}$ & -5.04 & 1.05 & $23.08^{* *}$ \\
More than one time & -3.10 & 1.01 & $9.34^{* *}$ \\
One time & .04 & .02 & $3.50 \mathrm{~ns}$ \\
Age & -1.22 & .28 & $19.30^{* *}$ \\
Gender (male) ${ }^{b}$ & -.00 & .00 & $5.77^{*}$ \\
Duration of driving experience & .51 & .26 & $3.65 \mathrm{~ns}$ \\
Driving theory test performance (at the first attempt) & -.25 & .27 & $.82 \mathrm{~ns}$ \\
On-road driving test performance (at the first attempt) & & .58 & $.03 \mathrm{~ns}$ \\
Learning to drive $^{\mathrm{c}}$ & -.11 & .57 & $.00 \mathrm{~ns}$ \\
Only with driving instructor & -03 & & \\
With driving instructor and under supervision of other drivers & .12 & & \\
Nagelkerke $\mathrm{R}^{2}$ & $42.27^{* *}$ & \\
Chi-square & & & \\
\hline
\end{tabular}

${ }^{*} \mathrm{p}<.01 ;{ }^{*} \mathrm{p}<.001 ;{ }^{\mathrm{a}}$ reference category - no fines for traffic rules violations; ${ }^{\mathrm{b}}$ reference category - females $;{ }^{\mathrm{c}}$ reference category with driving instructor, other drivers, and independently. 
lower in our sample compered to international data. For example, Boufous et al. (2011) reported that approx. 65 percent of Australian candidates pass their on-road test at first attempt. a bit lower numbers were observed in the Netherlands and UK: respectively 48 percent (de Winter, de Groot, Mulder, Wieringa, Dankelman, \& Mulder, 2009) and 43-48 percent depending on the information source (Baughan et al., 2006; Statista, 2018; Nyberg \& Gregersen, 2007; Sexton \& Grayson, 2010; Wells et al., 2008). Singapore police force (2018) declared that first-time onroad test passing rates depended on driving school and varied from 35.6 to 61 percent. It appears that Baughan and colleagues (2006) suggested a good explanation of such low first-time passing rates: firstly, many learner drivers come to on-road driving test not skilled enough and more likely are trying their luck than demonstrating competence to drive a vehicle properly. And secondly, multiple failures on on-road driving test might be related to the overestimation of candidates' own driving skills because of high level of support from their driving instructors and parents or because of competition with friends. Also driving test performance might be related to wrong attribution of a failure on driving with instructor either during the test to external factors (such as bad examiner, challenging situation or behaviour of other drivers) but not to lack of own driving skills (Baughan et al., 2006). On the other hand, learner drivers might underestimate their driving competence or feel too anxious prior to and during tests (Boufous et al., 2011).

Current findings revealed that not more diverse learning to drive, but longer independent driving experience and being male predicted the probability of being fined for the traffic violations. The fact that males violate traffic rules more often than females is not surprising and repeats previous findings (Ho \& Gee, 2008; Nyberg \& Gregersen, 2007). Also, these results confirmed findings of Maycock \& Forsyth (1997) that there was no relation between driving training experience and later accident involvement. Meanwhile, the relationship between driving experience and traffic offences during the first year of driving is quite obvious. The longer novice driver drives, the more traffic violations he or she commits and the greater chances of being caught by the police are (Baughan et al., 2006; Sexton \& Grayson, 2010; Tao, Zhang, \& Qu, 2017). And this finding is very important for novice drivers, as they may have the impression that if they repeatedly violated traffic rules and do not experience any negative consequences, such behaviour is reasonable and would continue.

Contrary to expectations, performance on onroad driving test was not related to either traffic offences or accident involvement. But, as expected, the first-time passers of theory test were less prone to violate traffic rules during independent driving. Thus, it shows that knowing the traffic rules might lead to the compliance. The absence of any other relations might be due to very low rates of violations (12.5 percent) and accident involvement (3.5 percent) in our sample. Such small numbers of offenders reduced the statistical power to detect significant relationships between the analysed variables (Tabachnick, Fidell, \& Osterlind, 2001). Unfortunately, the prediction of accident involvement was even not possible. Thus, this self-selection bias is the major limitation of this study. It might be that this happened because of voluntary participation in the study as statistical data provide much higher numbers of recorded offences in Lithuania (Lithuanian Police Service, 2017; Recorded accident statistics in Lithuania, 2016) not mentioning self-reported violations for which novice drivers were not fined.

Acknowledgements: This research was funded by a grant from the Research Council of Lithuania (grant No. GER-005/2015).

\section{REFERENCES}

Baughan, C., \& Sexton, B. F. (2002). Do driving test errors predict accidents?: Yes and no. In G. B. Grayson (Ed.), Behavioural research in road safety XI: Proceedings of the 11th seminar on behavioural research in road safety (pp. 252-268). Retrieved from https://trid.trb.org/View/734125

Baughan, C., Sexton, B., Simpson, H. M., Chinn, l., \& Quimby, A. R. (2006). Novice driver safety and the British practical driving test (TRL652).

Berdoulat, E., Vavassori, D., \& Sastre, M. T. M. (2013). Driving anger, emotional and instrumental aggressiveness, and impulsiveness in the prediction of aggressive and transgressive driving. Accident Analysis and Prevention, 50, 758-767.

Boccara, V., Delhomme, P., Vida-Gomel, C., \& Rogalski, J. (2011). Development of students drivers' self-assessment accuracy during French driver training: Self-assessments compared to instructors' assessments in three risky driving situations. Accident Analysis and Prevention, 43, 1488-1496.

Borowsky, A., Shinar, D., \& Oron-Gilad, T. (2010). Age, skill, and hazard perception in driving. Accident Analysis and Prevention, 42, 1240-1249. 
Boufous, S., Ivers, R., Senserrick, T., \& Stevenson, M. (2011). Attempts at the practical on-road driving test and the hazard perception test and the risk of traffic crashes in young drivers. Traffic injury prevention, 12(5), 475-482.

Cacciabue, P. C. (2007). Modelling driver behaviour in automotive environments: critical issues in driver interactions with intelligent transport systems. Springer-Verlag New York Inc.

De Winter, J. C. F. (2013). Predicting self-reported violations among novice license drivers using pre-license simulator measures. Accident Analysis and Prevention, 52, 71-79.

De Winter, J. C. F., De Groot, S., Mulder, M., Wieringa, P. A., Dankelman, J., \& Mulder, J. A. (2009). Relationships between driving simulator performance and driving test results. Ergonomics, 52(2), 137-153.

Ge, Y., Qu, W., Jiang, C., Du, F., Sun, X., \& Zhang, K. (2014). The effect of stress and personality on dangerous driving behavior among Chinese drivers. Accident Analysis and Prevention, $73,34-40$.

Harré N., Foster S., O’Neill M. 2005. Self-enhancement, crashrisk optimism, and the impact of safety advertisements on young drivers. British Journal of Psychology, 96, 215-230.

Harris, P. B., Houston, J. M., Vazquez, J. A., Smither, J. A., Harms, A., Dahlke, J. A., \& Sachau, D. A. (2014). The Prosocial and Aggressive Driving Inventory (PADI): a self-report measure of safe and unsafe driving behaviors. Accident Analysis and Prevention, $72,1-8$.

Ho, R., \& Gee, R. Y. (2008). Young men driving dangerously: Development of the motives for dangerous driving scale (MMDS). Australian Journal of Psychology, 60(2), 91-100.

Isler, R. B., Starkey, N. J., Sheppard, P., \& Yu, C. (2008). Piloting a telemetric data tracking system to assess post-training real driving performance of young novice drivers. In L. Dorn (Ed.) Driver Behaviour and Training, (pp. 17-29).

Lithuanian Police Service (2017). Retrieved December 12, 2017 from http://lkpt.policija.lrv.lt/uploads/lkpt.policija/documents/files/statistika/KET\%20201701-11\%20men.pdf

Maycock, G., \& Forsyth, E. (1997). Cohort study of learner and novice drivers. Part 4: Novice driver accidents in relation to methods of learning to drive, performance in the driving test and self-assessed driving ability and behaviour. (TRL275).

Møller, M., \& Haustein, S. (2014). Peer influence on speeding behaviour among male drivers aged 18 and 28. Accident Analysis and Prevention, 64, 92-99.

Mynttinen, S., Sundstrom, A., Koivukoski, M., Hakuli, K., Keskinen, E., \& Henriksson, W. (2009). Are novice drivers overconfident? a comparison of self-assessed and examiner-assessed driver competences in a Finnish and Swedish sample. Transportation Research Part F, 12, 120-130.

Nyberg, A., \& Gregersen, N. P. (2007). Practicing for and performance on drivers license tests in relation to gender differences in crash involvement among novice drivers. Journal of Safety Research, 38(1), 71-80.

Poó, F. M., \& Ledesma, R. D. (2013). a study on the relationship between personality and driving styles. Traffic Injury Prevention, 14(4), 346-352.
Ram, T., \& Chand, K. (2015). Effect of drivers' risk perception on safe driving attitude. International Journal of Vehicle Safety, $8(3), 218-232$.

Recorded accident statistics in Lithuania (2016). Retrieved June 22, 2017 from https://lakd.Irv.lt/uploads/lakd/documents/ files/Paslaugos/Inforinkmenos/statistika_2012-2015.pdf

Redshaw, S. (2005). Young drivers developing personal control. Youth Studies Australia, 24(3), 37-41.

Scott-Parker, B., Watson, B., King, M. J., \& Hyde, M. K. (2014). "I drove after drinking alcohol" and other risky driving behaviors reported by young novice drivers. Accident Analysis and Prevention, 70, 65-73.

Šeibokaitè, L., Endriulaitienè, A., Markšaitytè, R., \& Žardeckaitė-Matulaitienė, K. (2011). Besimokančiujų vairuoti asmenybės bruožų ir požiūrio ị eismo saugumą sąsajos [Correlation of personality traits and attitudes toward traffic safety in drivers-learners]. Psichologija pokyčiu laikotarpiu [Psychology in the period of changes]: Lietuvos psichologu kongresas [The Congress of Lithuanian Psychologists], May 6-7, Kaunas, 72-73.

Sexton, B., \& Grayson, G. (2010). The accident history and behaviours of new drivers who pass their first practical driving test. TRL Published Project Report.

Shope, J. T. (2006). Influences on youth driving behavior and their potential for guiding intervention to reduce crashes. Injury Prevention, 12, 9-14.

Shope, J. T., Raghunathan, T. E., \& Patil, S. M. (2003). Examining trajectories of adolescent risk factors as predictors of subsequent high-risk driving behavior. Journal of Adolescent Health, 32, 214-224.

Simons-Morton, B., \& Ehsani, J. P. (2016). Learning to drive safely: reasonable expectations and future directions for the learner period. Safety, 2(4), 20.

Singapore police force (2018). Passing rates. Retrieved March 22, 2018 from https://www.police.gov.sg/resources/traffic-matters/ getting-a-licence/motorcar/passing-rates/practical-driving$\underline{\text { schools }}$

Starker, N. J., \& Isler, R. B. (2016). The role of executive function, personality and attitudes to risks in explaining self-reported driving behaviour in adolescent and adult male drivers. Transportation Research Part F, 38, 127-136.

Statista (2018). The Statistics Portal, UK. Retrieved March 22, 2018 from https://www.statista.com/statistics/301246/ practical-driving-tests-pass-rate-in-the-united-kingdom-bygender/

Tabachnick, B. G., Fidell, L. S., \& Osterlind, S. J. (2001). Using multivariate statistics. Boston: Allyn and Bacon.

Tao, D., Zhang, R., \& Qu, X. (2017). The role of personality traits and driving experience in self-reported risky driving behaviors and accident risk among Chinese drivers. Accident Analysis and Prevention, 99, 228-235.

Traffic safety basic facts (2016). European Commision. Retrieved March 5, 2017 from https://ec.europa.eu/transport/road safety/sites/roadsafety/files/pdf/statistics/dacota/bfs2016 main_figures.pdf 
Trógolo, M. A., Melchior, F., \& Medrano, L. A. (2014). The role of difficulties in emotion regulation on driving behavior. Journal of Behavior, Health and Social Issues, 6(1), 107-117.

Vassallo S., Smart D., Spiteri M., Harris A., Cockfield S., \& Harrison W. (2014). Stability of risky driving from late adolescence to early adulthood. Accident Analysis and Prevention, $72,161-168$.

Vassallo, S., Smart, D., Sanson, A., Harrison, W., Harris, A., Cockfield, S., \& McIntyre, A. (2007). Risky driving among young Australian Drivers: Trends, precursors and correlates. Accident Analysis and Prevention, 39, 444-58.

Wells, P., Tong, S., Grayson, G., \& Jones, E. (2008). Cohort II-A study of learner and new drivers-volume 1-main report, volume 2-questionnaires and data tables. Road Safety Research Report.

Yang, J., Du, F., Qu, W., Gong, Z., \& Sun, X. (2013). Effects of personality on risky driving behavior and accident involvement for Chinese drivers. Traffic Injury Prevention, 14(6), 565-571. 